\title{
INVESTIGATION INTO THE AETIOLOGY AND TREATMENT OF PICA*
}

\author{
BY

\begin{abstract}
PHILIP LANZKOWSKY $\dagger$
From the Department of Child Health, University of Cape Town and Red Cross War Memorial Children's Hospital, Rondebosch, Cape Town, South Africa
\end{abstract}

(RECEIVED FOR PUBLICATION OCTOBER 6, 1958)

The name pica is derived from the Latin word meaning magpie. In reviewing the literature no adequate definitions are to be found. Those of Hubrigkt (1562) and Schrey (1719), as quoted by Cooper (1957), are antiquated and of historical interest only. Pica could be described as a perversion of appetite with persistent and purposeful ingestion of unsuitable substances, seemingly of no nutrient value. It is associated with the passage of these substances unchanged in the stool, and with radiological evidence of their presence in the gut when they are radio-opaque.

Pica is world-wide in distribution, and occurs at all ages. Each individual or local group seems to specialize in one direction, eating only a particular type of material. Many small children, at some time in early life, put in their mouths and occasionally swallow inedible matter, but this is so well recognized that it causes only the mildest of domestic upsets. Even if an occasional individual does so repeatedly, medical advice is not sought unless the performance in this respect becomes spectacular.

The purpose of this paper is to report on a series of children suffering from pica.

My attention was drawn to pica by a casual remark passed by the mother of a boy who was being treated for hypochromic anaemia, that since the commencement of iron medication the boy had stopped eating dirt.

For centuries writers have recorded observations on pica, but the most recent reports, however, still left the matter of therapy an unsolved problem. The earliest writers centred their attention on the condition as it affected pregnant women.

Boezo (1638), Hancock (1831), Nouverre (1833), Segond (1833), Cragin (1835), Gould (1876),

* Paper presented at the Postgraduate Seminar, Red Cross War Memorial Children's Hospital, Rondebosch, Cape Town, September, 1958, and at the South African Paediatric Congress, Pretoria, October, 1958.

$\dagger$ Recipient of a Dr. C. L. Herman Research Grant, University of Cape Town Staff Research Fund.
Kovatsch (1879), Gros (1903), Tosatti (1907), Major (1935), all quoted by Cooper (1957); Livingstone as cited by Waller (1874); Duprey (1900); Orr and Gilks (1931); Dickins and Ford (1942); and De Castro (1952) all mentioned an association between pica and minerals; some of them suggested iron for treatment. Hancock attributed pica to ' paucity of good blood and lack of proper nutrition'. Segond, Cragin, Duprey, Gros, and Tosatti all indicated that anaemia was part of the picture and Gould recorded a cure after iron therapy. According to Waller, the explorer Livingstone commented on clay and earth-eating and stated that it was 'the cause of bloodlessness' amongst the African tribes in Zanzibar. Orr and Gilks and De Castro realized that the 'edible earths' were rich in sodium, iron and calcium, and Dickins and Ford suggested that negro children might eat dirt to make up for an iron deficiency in their diet.

Unfortunately, many of these observers clouded the issue by introducing simultaneously other feasible explanations for the pica. Lack of proper nutrition was incriminated by Hancock. Duprey admitted that his subjects had a meagre diet. Rake (1884) thought that economic reasons, with the idea of saving food, might be a basic cause amongst the Hindus in Trinidad. Gelfand (1945) noted that pica was common in Kenya amongst the African tribes (Kikuyu) living mainly on a vegetarian diet as contrasted with its absence in the high-proteineaters (Masai). Dickins and Ford (1942) confirmed this observation in rural Negro school children in the Mississippi area, where they found the incidence of pica significantly higher in children consuming fewer iron-rich foods. Cooper (1957) found a greater incidence of nutritional problems in children suffering from pica and thought that poor nutrition might be the underlying factor. Debilitating disease such as tuberculosis and malignant or tropical disease was thought by Gelfand to be at the root of the inanition and death which had been known as 
'cachexia Africana', previously thought to be a pathological form of geophagy.

Other possible explanations have been advanced. A depraved appetite was alleged by Nouverre (1833) to be at the root of the trouble. Livingstone agreed and stated that both slaves and rich men were affected and the condition was called 'safura' by the Africans. Duprey described it as a craving so strong that the coolies of Carriacou carried gravel around on their person and would cry and beg for the dirt which they cherished so much. Butterworth (1909) described as a habit the somewhat allied disorder of swallowing hair.

Mental deficiency was invoked by Kanner (1948) who found that 16 out of 30 children with pica studied by him were severely retarded and almost all were below average intelligence. As additional causes he added faulty habit training and parental neglect. Still had denied this in 1915 but stated that such children had a 'nervous temperament' and Cooper's finding, in 1957, that the I.Q. of her picagroup was $87 \cdot 2 \%$ supports Still's contention.

Infestation by intestinal parasites has been commonly suspected to be an associated factor and, though ankylostomiasis was frequently incriminated, many different types of worms have been mentioned. Duprey favoured ankylostomiasis. Gelfand (1945) was emphatically opposed to this view. Kovatsch and Dukes (1884) associated pica with ascaris; Gros (1903) with ascaris and oxyuris; Mathieu (1927) as quoted by Cooper, with ascaris, oxyuris, trichuris, and hymenolepis, and Major (1935) with oxyuris.

Causes of a more abstruse nature have been suggested. Gelfand pointed out that pica is common practice in the Rhodesias, Nyasaland, Portuguese East Africa, the Congo, East, West and North Africa. Earth-eating is frequently closely associated with the religious or magical beliefs of the natives and is not a subject for discussion with the white man. There is a presumed personal and spiritual bond between the land and the tribe or clan living on it who pay homage, and in some instances make yearly sacrifices, to the land. On entering alien soil an African may, as an act of homage, eat a little of it. His wife, children, and even the baby must also partake in this rite. Furthermore, in recognizing the fertile powers of the earth it is assumed that if a woman eats earth she will be more fertile before pregnancy and by continuing to eat it will increase her powers of lactation. Her children are brought up in that belief from the day they are born. This aspect of the problem has nothing to do with the universally recognized cravings of pregnant women.

Mothers may withhold information as to the occurrence of pica in their children and this makes an assessment of its incidence more difficult. Dickins and Ford (1942), however, found that $26 \%$ of boys and $25 \%$ of girls in Mississippi ate dirt, and De Castro (1952) found that geophagy was common amongst school children in Bahia, Brazil. Cooper (1957) stated that $21.9 \%$ of children referred to the Mothers' Advisory Service Clinic at Baltimore had a history of pica.

Although children with pica may have a craving for a variety of substances it is fortunate that most of these are inert and, although they occasionally lead to minor ailments do not cause any serious disturbance to the health of the child. There is, however, one type of poisoning which these pica children may acquire, and that is lead poisoning. Ruddock (1924), McKhann (1926), Stetson (1947), Tanis (1955), Williams, Kaplan, Couchman and Sayers (1955) as quoted by Cooper, have each recorded a series of cases of lead poisoning due to ingestion of paint and they state that pica is an important aetiological factor in lead poisoning. Nims (1842), and Peak (1857), as quoted by Cooper (1957) and Rake (1884), a century ago recorded deaths from intestinal perforation or obstruction caused by the ingestion of gravel, stone or sand. Even with modern surgery, ingestion of inedible material can produce major hazards in the shape of bezoars from the perpetual swallowing of hair (trichobezoar), rags, threads or fibrous plant roots (phytobezoar) and by such unlikely material as wellington boots, india rubber, and rubber doorstops (Butterworth, 1909; Kanner, 1948; Ford, 1958).

From this welter of possibilities no rational line of thought seems to have emerged. Iron deficiency has been mooted and iron therapy suggested as an aid to treatment but it has not been shown that iron alone could stop the perversion. Malnutrition is not uncommonly associated with pica but there is no evidence to prove that malnutrition is essential for the development of this condition. Worm infestation has been blamed but the indictment left unproven. All these should be susceptible to clinical testing; factors beyond human control such as mental deficiency, depraved appetite, religious and tribal customs might take on a new significance or lose entirely the hypothetical place which they at present occupy in the problematical aetiology of pica.

\section{Present Investigation}

Children attending the Red Cross Hospital outpatient department who presented either with pica, or where pica was part of the history, were investigated. During a five-month period there were 12 such patients seen at the hospital, 10 of them 
CLINICAL FEATW̛̉RES

\begin{tabular}{|c|c|c|c|c|}
\hline Case No. & Age, Sex, Race, Birthweight & Symptoms, Duration, Type & Severity & Worms $\supseteqq$ \\
\hline 1 & $47 / 12 . \quad$ M. Col. & $\begin{array}{l}\text { Pica. Over } 2 \text { yr. Black soil. } \\
\text { Pieces of brick }\end{array}$ & $\begin{array}{l}\text { Daily. Pockets of sand carried. } \\
\text { Scratched walls to get brick }\end{array}$ & Ascaris \\
\hline 2 & 67/12. M. Col. 13 lb. $3 \frac{1}{2} \mathrm{oz}$. & $\begin{array}{l}\text { Pica. } 3 \frac{1}{2} \text { yr. Sand at first. Pebbles } \\
\text { only, } 3 \text { yr. }\end{array}$ & $\begin{array}{l}\text { Daily. Attended every hospital in } \\
\text { town and several physicians }\end{array}$ & Ascaris \\
\hline 3 & $24 / 12 . \quad$ F. Col. & Pica. 1 yr. Sand & Intermittently & Ascaris \\
\hline 4 & 38/12. F. White. 8 lb. $\frac{1}{2}$ oz. & $\begin{array}{l}\text { Abdominal pain. Pica. } 2 \frac{1}{2} \text { yr. Small } \\
\text { stones. Pieces of brick. White sand, } \\
\text { soil. Pieces of wood. } \\
\text { Anorexia }\end{array}$ & Daily & Ascaris \\
\hline 5 & $21 / 12 . \quad$ F. Col. $6 \mathrm{lb} .3 \mathrm{oz}$. & $\begin{array}{l}\text { Worms. Pica over } 1 \text { yr. Sand. } \\
\text { Anorexia }\end{array}$ & $\begin{array}{l}\text { Daily. Child had to be restrained. } \\
\text { Scratched walls to get brick }\end{array}$ & $\begin{array}{l}\text { Ascaris } \\
\text { Tapeworm }\end{array}$ \\
\hline 6 & $\begin{array}{l}18 / 12 . \\
\text { Control }\end{array}$ & $\begin{array}{l}\text { Pica. } 1 \text { yr. Sand. Little stones. } \\
\text { Coal. Pieces of wood } \\
\text { Diarrhoea } \\
\text { Anorexia } \\
\text { Restless }\end{array}$ & $\begin{array}{l}\text { Daily. Removed spoons from table to } \\
\text { eat sand with }\end{array}$ & No \\
\hline 7 & 2 2!12. M. Col. $7 \mathrm{lb}$ & $\begin{array}{l}\text { Diarrhoea. Pica over I yr. Sand, } \\
\text { earth. Ash } \\
\text { Worms } \\
\text { Anorexia }\end{array}$ & $\begin{array}{l}\text { Daily. 'Handfuls every day. It was } \\
\text { his diet' states mother. } \\
\text { Licked sand off boots and off the floor. } \\
\text { Required restraint. Mother left work } \\
\text { on account of the severity of his con- } \\
\text { dition }\end{array}$ & Ascaris \\
\hline 8 & 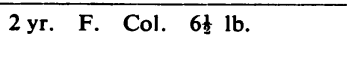 & $\begin{array}{l}\text { Pica } 6 \mathrm{~m} . \text { Sand. Small stones. } \\
\text { Diarrhoea }\end{array}$ & Daily. Restrained & Ascaris \\
\hline 9 & $39 / 12 . \quad$ F. Col. $5 \mathrm{lb}$. & $\begin{array}{l}\text { Pica } 2 \text { yr. Sand. Stones. Clay } \\
\text { Diarrhoea }\end{array}$ & Daily. Restrained & Ascaris \\
\hline 10 & 1 10/12. M. White. $9 \mathrm{lb} .3 \mathrm{oz}$. & $\begin{array}{l}\text { Pica over } 1 \text { yr. Sand. Pebbles } \\
\text { stones } \\
\text { Anorexia }\end{array}$ & $\begin{array}{l}\text { Daily. 'Was never, without a stone or } \\
\text { sand in the mouth'. Amount of sand } \\
\text { eaten was incredible. Restrained }\end{array}$ & 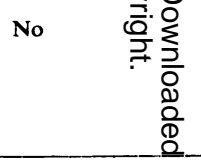 \\
\hline 11 & 34/12. F. Col. & $\begin{array}{l}\text { Diarrhoea. Pica, ?. Sand } \\
\text { Cough }\end{array}$ & Daily & $\begin{array}{l}\text { Ascaris } \\
\text { Trichura trich }\end{array}$ \\
\hline 12 & 4 yr. M. Col. 8 lb. 5 oz. & Abdominal mass. Pica 3 yr. Sand & Daily & Ascaris \\
\hline
\end{tabular}

were Cape Coloured and two were white. There were seven girls and five boys and their ages ranged from 1 year, 8 months to $6 \frac{1}{2}$ years. The duration of pica was from a minimum of six months to a maximum of three and a half years, in children of 2 and $6 \frac{1}{2}$ years respectively. In one case the pica was intermittent, with periods of a few weeks' respite, but in the remainder it was persistent and an almost daily occurrence. Of the 12 patients, seven sought advice because of pica, two for diarrhoea, and one of the others for each of the following complaints: abdominal pain, worms, and an abdominal mass with anaemia. Other associated complaints were anorexia and restlessness.

In most cases pica was so severe that the mothers had taken active steps to restrain the children. Most of them had been locked up indoors, for varying periods of time, away from a source of dirt. Under these conditions some would scratch at the walls in order to get access to pieces of brick and plaster. One constantly carried sand in his pockets in order to have a supply readily available all day. Another would lick sand off the boots of visitors and off the floor. One mother stated that the quantity of sand eaten was almost incredible. Most of the children were known to pass sand in their stools.

A wide variety of substances, depending upon their availability, was ingested. As white sand is common in the Cape it was eaten in nearly every 
1

OF PICA GROUP

\begin{tabular}{|c|c|c|c|c|}
\hline Intelligence & Behaviour & Appearance & Radiography & Response to Treatment \\
\hline $\begin{array}{l}\text { Average. Normal milestones. } \\
\text { Mother states 'bright lad' }\end{array}$ & Good & Well-nourished & $\begin{array}{l}\text { Opaque material compatible } \\
\text { with sand in colon }\end{array}$ & $\begin{array}{l}\text { Cured. Played in sand but did } \\
\text { not eat any. Appetite greatly } \\
\text { improved }\end{array}$ \\
\hline $\begin{array}{l}\text { Above average. Normal mile- } \\
\text { stones }\end{array}$ & Temper tantrums & Well-nourished & $\begin{array}{l}\text { Opaque material in bizarre sizes } \\
\text { and shapes in G.I. tract, mainly } \\
\text { in colon }\end{array}$ & Cured \\
\hline Average. Normal milestones & Well-behaved & Well-nourished & - & $\begin{array}{l}\text { Cured. Appetite greatly im- } \\
\text { proved. More energetic. Less } \\
\text { restless }\end{array}$ \\
\hline $\begin{array}{l}\text { Above average. Normal mile- } \\
\text { stones. Mother states 'cleverer } \\
\text { than older brother of } 5 \text { yr.' }\end{array}$ & Good & Well-nourished & No opaque material & $\begin{array}{l}\text { Cured Appetite greatly improved } \\
\text { Mother states 'more alive' }\end{array}$ \\
\hline $\begin{array}{l}\text { Above average. Normal mile- } \\
\text { stones. Very good memory }\end{array}$ & Good & Well-noy dished & - & $\begin{array}{l}\text { Cured. Dramatic improvement } \\
\text { in appetite }\end{array}$ \\
\hline $\begin{array}{l}\text { Above average. Normal mile- } \\
\text { stones. Good memory. Mother } \\
\text { states 'Cleverest child of five } \\
\text { siblings' }\end{array}$ & Good & $\begin{array}{l}\text { Well-nceurished. } \\
\text { Pallor }\end{array}$ & No opaque material & $\begin{array}{l}\text { I.M. sterile water: No change } \\
\text { in behaviour. I.M. Iron-dextran: } \\
\text { Cured. Less irritable. Appetite } \\
\text { improved }\end{array}$ \\
\hline $\begin{array}{l}\text { Above average. Normal mile- } \\
\text { stones. Speaks two languages } \\
\text { Well and counts very well }\end{array}$ & Good & Well-murished & - & $\begin{array}{l}\text { Cured. Appetite and general } \\
\text { behaviour improved }\end{array}$ \\
\hline Average. Normal milestones & Good & $\begin{array}{l}\text { Well-spurished } \\
\text { Pallor }+\end{array}$ & - & $\begin{array}{l}\text { Cured. Appetite greatly im- } \\
\text { proved. } \\
\text { lively }\end{array}$ \\
\hline Average & Good & $\begin{array}{l}\text { Well-nourished. } \\
\text { Pallor }+\end{array}$ & $\begin{array}{l}\text { Opaque material compatible with } \\
\text { sand in large bowel more on } R \text {. }\end{array}$ & $\begin{array}{l}\text { Cured. 'Skoon verandering'.* } \\
\text { Played and ate better }\end{array}$ \\
\hline Average. Normal milestones & $\begin{array}{l}\text { Temper tantrums. } \\
\text { Spiteful, difficult } \\
\text { child }\end{array}$ & Well-nourished & Opaque material in large bowel & $\begin{array}{l}\text { Cured. Vast improvement. } \\
\text { Mother stated 'a different child' } \\
\text { in appetite and less irritable. } \\
\text { Refused an orange which fell on } \\
\text { to sand whereas before treatment } \\
\text { deliberately rubbed most of food } \\
\text { in sand before eating it }\end{array}$ \\
\hline Average & Good & $\begin{array}{l}\text { Miserable, malnour- } \\
\text { ished } \\
\text { Severe pallor }\end{array}$ & No opaque material in G.I. tract & $\begin{array}{l}\text { Transfusion: no change. Only } \\
\text { cured after I.M. Iron-dextran }\end{array}$ \\
\hline Average. Normal milestones & Good & $\begin{array}{l}\text { Well-nourished. } \\
\text { Pallor. } \\
\text { Abdominal mass. } \\
\text { Histology : lympho- } \\
\text { sarcoma }\end{array}$ & Opaque material in G.I. tract & $\begin{array}{l}\text { Died from primary disease with- } \\
\text { out discharge from hospital }\end{array}$ \\
\hline
\end{tabular}

'clean change'.

case, either alone or in combination with other substances. Black soil, pieces of brick, stones (Fig. 1), pieces of wood, black coal, and clay were taken in addition to sand in varying combinations and amounts.

The appearance of the children was not conspicuously abnormal. There was no tell-tale appearance which would lead an observer to suspect the condition. The general standard of physique appeared to be normal (Fig. 2). Only one child showed overt clinical signs of undernutrition. Five showed clinical evidence of anaemia with pallor of the mucosae. One patient had a palpable abdominal mass, and a diagnosis of lymphosarcoma was made on biopsy. In the remaining cases all the systems were normal on physical examination. In no case was splenomegaly found. The clinical features for each individual are shown in Table 1.

One of the main reasons for this investigation was to determine whether an iron-deficiency existed. Haemoglobin, P.C.V. and M.C.H.C. estimations were done and peripheral smears were examined (Table 2). Unfortunately in the earlier cases haematological examination was incomplete.

The haemoglobin level ranged from $3.0 \mathrm{~g} . \%$ to $10.9 \mathrm{~g} . \%$ with a mean of $7.89 \mathrm{~g} . \%$ and a standard deviation of $2 \cdot 64$. The haemoglobin estimation was done by the oxyhaemoglobin method using a Klett-Summerson colorimeter.

The mean P.C.V. was $29.5 \%$ with a range from 


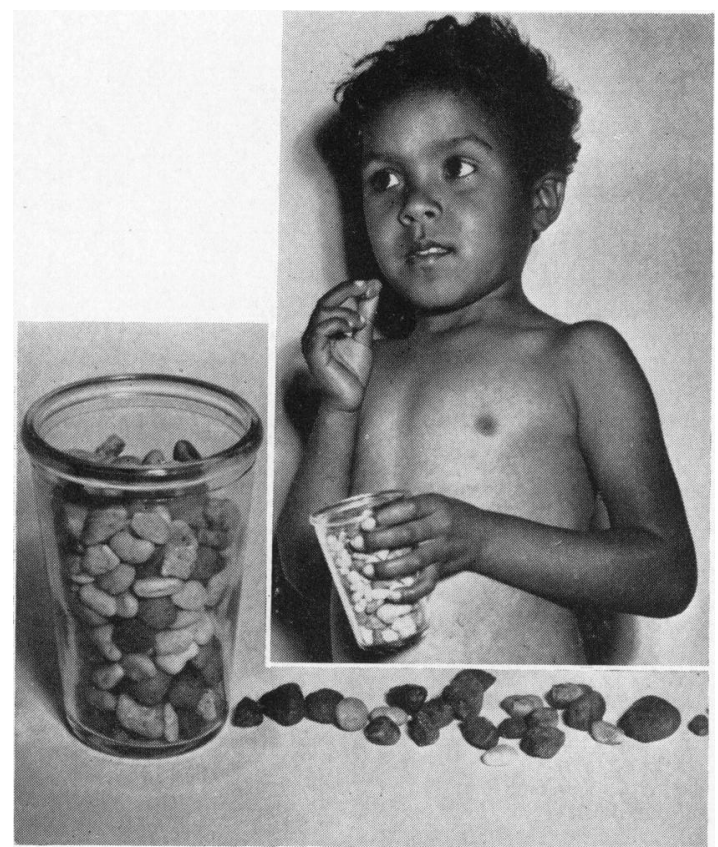

FIGS. 1 and 2.-Case 2. Daily diet of pebbles taken for three years by a coloured boy aged 6 years 7 months, with pica. Note normal physique.

$19 \%$ to $37 \%$ and a standard deviation of 6.68 .

The mean M.C.H.C. was $27.5 \%$ with a range from $21 \%$ to $32 \%$ and a standard deviation of 3.96.

Peripheral smears showed marked hypochromasia, anisocytosis and poikilocytosis in cases where the anaemia was of a severe degree, and all gradations of an iron deficiency pattern to normal red blood cells.

Serum protein estimations were done on 11 cases, by the Weichselbaum biuret method. Results showed a mean of $7 \cdot 19 \mathrm{~g}$. $\%$ for total serum proteins, $3.87 \mathrm{~g}$. $\%$ for serum albumin and $3.32 \mathrm{~g}$. $\%$ for serum globulin (Table 3).

Ten children $(83 \%)$ gave a history of ascaris infestation. One child had tapeworm and another Trichuris trichiura in addition to ascaris. Confirmatory evidence of worm infestation was looked for. Peripheral blood smears were obtained in five cases. These showed an eosinophilia of 5,7 . 8,8 , and $10 \%$ respectively and all had passed round. worms.

The mentality of the subjects was scrutinized. Contrary to expectation, the intelligence of the children as a whole in this survey was average, and, in a few instances, considered to be distinctly above average. No formal intelligence tests were applied but the intelligence was assessed by the author in conjunction with the parents and on the basis of developmental data, language, and social adjustment. While it is fully realized that this is only a rough guide to the I.Q., it is sufficient for this purpose to indicate that these children with pica were for practical purposes mentally normal.

The children did not appear to suffer from behaviour disorders. Ten of these children could be described as normally well-behaved children. Two, however, had temper tantrums.

Radiological examinations were done on eight cases. Five showed opaque material interpreted as sand or stones in the large bowel, and to a lesser extent in the small bowel (Figs. 3-6). In one of these the appendix was outlined and filled with sand (Fig. 7). None had a previous history of roentgenographic contrast studies and none had taken any medicines containing radio-opaque materials, e.g.

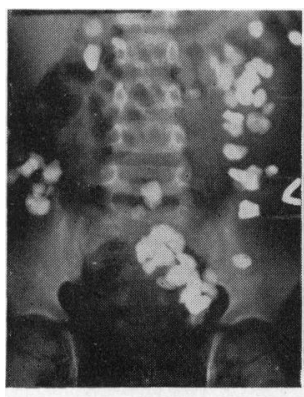

3

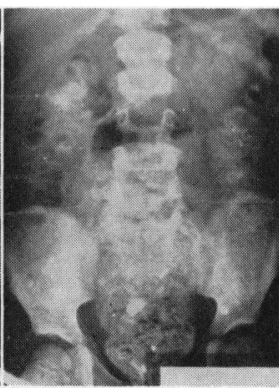

4

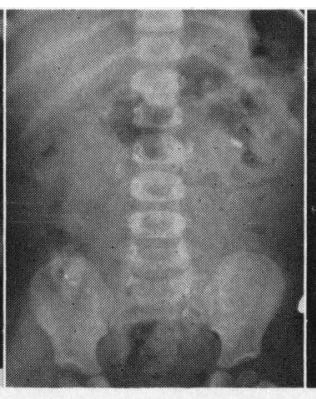

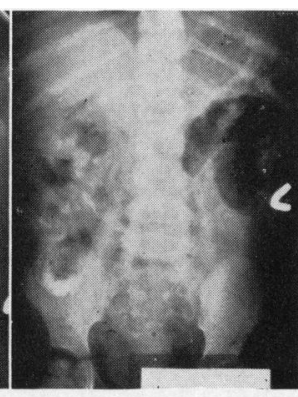

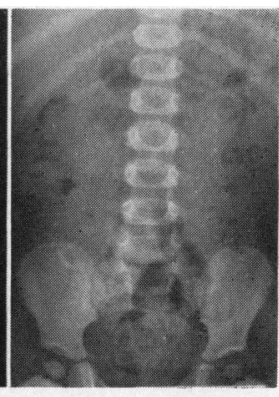

Fig. 3.-Case 2. Radio-opaque material of bizarre sizes and shapes compatible with stones in small and large intestine in coloured boy with pica.

FIG. 4.-Case 1. Radio-opaque material compatible with sand in colon in coloured boy with pica.

FIG. 5.-Case 10. Radio-opaque material compatible with sand in colon in white boy with pica.

Fig. 6.-Case 9. Radio-opaque material compatible with sand in caecum and ascending colon of coloured girl with pica.

Fig. 7.-Case 10. Radio-opaque material compatible with sand in the appendix in white boy with pica. 
TABLE 2

HAEMATOLOGICAL VALUES IN PICA GROUP

\begin{tabular}{|c|c|c|c|c|c|}
\hline Case No. & $\underset{(\mathrm{g} . \%)}{\mathrm{Hb}}$ & $\underset{(\%)}{\text { P.C.V. }}$ & $\underset{(\%)}{\text { M.C.H.C. }}$ & $\begin{array}{c}\text { Morphology } \\
\text { Red Blood Corpuscles }\end{array}$ & $\begin{array}{l}\text { Eosinophil } \\
\text { Count }(\%)\end{array}$ \\
\hline 1 & $8 \cdot 6$ & 32 & 30 & Hypochromasia slight & - \\
\hline 2 & $10 \cdot 9$ & 37 & 29 & Normal & 7 \\
\hline 3 & $8 \cdot 9$ & 28 & 32 & - & - \\
\hline 4 & $10 \cdot 6$ & 34 & 31 & Normal & - \\
\hline 5 & $9 \cdot 7$ & - & - & Hypochromasia slight & 8 \\
\hline 6 & $7 \cdot 9$ & 32 & 24 & Hypochromasia slight & - \\
\hline 7 & $9 \cdot 5$ & - & - & $\begin{array}{l}\text { Hypochromasia slight } \\
\text { Poikilocytosis slight }\end{array}$ & 10 \\
\hline 8 & $4 \cdot 1$ & 20 & 21 & $\begin{array}{l}\text { Hypochromasia }++ \\
\text { Anisocytosis }+ \\
\text { Polychromasia slight }\end{array}$ & 8 \\
\hline 9 & $4 \cdot 6$ & 19 & 24 & $\begin{array}{l}\text { Hypochromasia }+++ \\
\text { Anisocytosis slight } \\
\text { Polychromasia slight }\end{array}$ & - \\
\hline 10 & $9 \cdot 7$ & 34 & 29 & - & - \\
\hline 11 & $3 \cdot 0$ & 一 & - & $\begin{array}{l}\text { Hypochromasia }+++ \\
\text { Anisocytosis }++ \\
\text { Poikilocytosis }++ \\
\text { Target cells few }\end{array}$ & - \\
\hline 12 & $7 \cdot 0$ & - & - & $\begin{array}{l}\text { Hypochromasia }+ \\
\text { Anisocytosis }+\end{array}$ & 5 \\
\hline Total cases & 12 & 8 & 8 & - & 5 \\
\hline Mean & $7 \cdot 89$ & $29 \cdot 5$ & $27 \cdot 5$ & - & 8 \\
\hline $\begin{array}{l}\text { Standard } \\
\text { deviation }\end{array}$ & $2 \cdot 64$ & $6 \cdot 68$ & $3 \cdot 96$ & - & - \\
\hline
\end{tabular}

bismuth or barium. Of the three cases in which there was no radiographic evidence, two had a history of diarrhoea in addition to pica.

Once the foregoing investigations had been completed therapy was commenced (Table 4). Intramuscular iron-dextran compound (Imferon) in doses varying from $200-400 \mathrm{mg}$. was given in nine cases. The total dose of intramuscular iron-dextran

TABLE 3

SERUM PROTEIN ESTIMATIONS IN PICA GROUP

\begin{tabular}{|c|c|c|c|}
\hline Case No. & $\begin{array}{l}\text { Total } \\
\text { Serum Proteins } \\
(\text { g. } \%)\end{array}$ & $\underset{(\text { g. } \%)}{\text { Serum }}$ & $\underset{\text { Globulin }}{\text { Ser. \%) }}$ \\
\hline $\begin{array}{r}1 \\
2 \\
3 \\
4 \\
5 \\
6 \\
7 \\
8 \\
9 \\
10 \\
11 \\
12\end{array}$ & $\begin{array}{c}7 \cdot 80 \\
7 \cdot 38 \\
6.08 \\
8.40 \\
7.49 \\
6.96 \\
6 \cdot 60 \\
7.50 \\
7.42 \\
6.92 \\
7 \cdot 58 \\
-\end{array}$ & $\begin{array}{c}3 \cdot 53 \\
4 \cdot 54 \\
3 \cdot 38 \\
3.74 \\
4 \cdot 65 \\
3.80 \\
3.60 \\
3.74 \\
3.77 \\
4 \cdot 85 \\
2.96 \\
-\end{array}$ & $\begin{array}{c}4 \cdot 27 \\
2 \cdot 84 \\
2 \cdot 70 \\
4 \cdot 66 \\
2 \cdot 84 \\
3 \cdot 16 \\
3 \cdot 00 \\
2 \cdot 76 \\
3 \cdot 65 \\
2 \cdot 07 \\
4 \cdot 62 \\
-\end{array}$ \\
\hline Mean g. $\%$ & $7 \cdot 19$ & $3 \cdot 87$ & $3 \cdot 32$ \\
\hline $\begin{array}{l}\text { Standard } \\
\text { deviation }\end{array}$ & 0.66 & 0.55 & 0.82 \\
\hline
\end{tabular}

compound (Imferon) was given in one injection and calculated, in each case, according to the original haemoglobin level and the body weight.* One of

*The formula used was $9 \mathrm{~W}+\frac{\mathrm{W}}{6}(100-\mathrm{Hb} \%)=\mathrm{mg}$. of iron.

Where $\mathbf{W}=$ Weight of patient in pounds. $\mathrm{Hb} \%=$ Observed haemoglobin percentage.

TABLE 4 RESPONSE TO TREATMENT IN PICA GROUP

\begin{tabular}{|c|c|c|c|}
\hline Case No. & $\begin{array}{l}\text { Haemoglobin } \\
\text { Before } \\
(\text { g. } \%)\end{array}$ & $\begin{array}{c}\text { Haemoglobin } \\
\text { After } \\
\text { (g. } \%)\end{array}$ & $\begin{array}{l}\text { Treatment } \\
\text { I.M. Iron-Dextran } \\
\text { Compound } \\
\text { (mg.) }\end{array}$ \\
\hline $\begin{array}{c}1 \\
2 \\
3 \\
4 \\
5 \\
6 \\
\text { (Control) } \\
7 \\
8 \\
9 \\
10 \\
11 \\
12\end{array}$ & $\begin{array}{r}8 \cdot 6 \\
10 \cdot 9 \\
8 \cdot 9 \\
10 \cdot 6 \\
9 \cdot 7 \\
7 \cdot 9 \\
9 \cdot 5 \\
4 \cdot 1 \\
4 \cdot 6 \\
9 \cdot 7 \\
3 \cdot 0 \\
7 \cdot 0\end{array}$ & $\begin{array}{r}11 \cdot 7 \\
10 \cdot 9 \\
11 \cdot 9 \\
11 \cdot 3 \\
11 \cdot 8 \\
10 \cdot 8 \\
12 \cdot 2 \\
10 \cdot 5 \\
10 \cdot 9 \\
11 \cdot 6 \\
9 \cdot 0 \\
14 \cdot 5\end{array}$ & 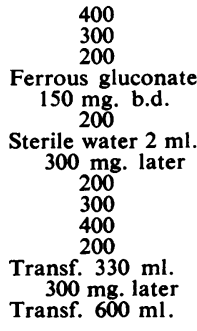 \\
\hline Mean & $7 \cdot 89$ & $11 \cdot 43$ & $278 \mathrm{mg}$. \\
\hline $\begin{array}{l}\text { Standard } \\
\text { deviation }\end{array}$ & $2 \cdot 64$ & $1 \cdot 29$ & - \\
\hline
\end{tabular}


these nine cases was initially used as a control and given $2 \mathrm{ml}$. of intramuscular sterile water. This did not cause any change in the child's behaviour and the severity of the pica persisted unchanged. He was subsequently given $300 \mathrm{mg}$. intramuscular iron-dextran compound (Imferon) and responded dramatically with complete cessation of the pica.

Two patients who were admitted to hospital, one with a diagnosis of lymphosarcoma and the other with diarrhoea and severe iron deficiency anaemia, received blood transfusions. The one with lymphosarcoma died without being discharged from hospital and does not figure in these comments. The other was only seen again two months after her discharge. The mother then reported that she had continued eating sand and dirt. On examination her haemoglobin had fallen from $9 \mathrm{~g}$. \% on discharge to $5 \mathrm{~g}$. \%. She was then given intramuscular iron-dextran compound and her pica ceased dramatically within 10 days.

One white patient was given oral ferrous gluconate.

The results of treatment on the whole, were highly gratifying. In one child only (Case 2 ), there was no change in the haemoglobin level. The remaining children showed a marked rise in haemoglobin level after treatment. The mean haemoglobin on completion of treatment was $11.43 \mathrm{~g}$. $\%$, showing a mean rise of $3.54 \mathrm{~g} . \%$.

All the children showed a complete cure of their pica, usually within one to two weeks of commencement of treatment and in some instances in a shorter time. Several of the children who had eaten sand for many years continued to play with sand and stones, but had no inclination to eat these substances. The mothers were instructed not to restrict their activities. All the children showed the usual beneficial effects of iron therapy on behaviour, appetite and sense of well-being. Many cases have now been followed for over a year without a recurrence of pica.

The five cases which before treatment had shown radio-opaque material in the bowel all showed complete radiographic clearing within 10 days.

\section{Discussion}

In the course of this study some details complementary to the main issues have been noted. Although the alleged major factors in the production of pica have been examined there are other possibilities which cannot be entirely ignored. It is often reported that pica occurs more frequently in children coming from a poor socio-economic background. The present series, however, did not show this. The mean weekly income, assessed on a per capita basis, amongst the Cape Coloured children in this series was $26 \cdot 13$ shillings, as compared with 13.08 shillings for a control group of 50 unselected out-patients. This shows a statistically significant difference between the weekly income of the two groups. The pica group are apparently better off financially. The reason for this marked discrepancy in socioeconomic status may be that the mothers of low socio-economic status are too occupied to attend to what they consider to be a mere aberration in the child's eating habits.

The birth weights of these children were investigated, since it had been shown by Cooper (1957) that the percentage of the premature-born amongst children suffering from pica was abnormally high. The mean birth weight of the children in this series was $7 \mathrm{lb}$. $15 \frac{1}{2} \mathrm{oz}$. with a range from $13 \mathrm{lb}$. $3 \frac{1}{2} \mathrm{oz}$. to $5 \mathrm{lb}$. The mean birth weight for Cape Coloured children in a control group of 74 normal births studied by the author was found to be $6 \mathrm{lb} .15 \frac{1}{2} \mathrm{oz}$. This demonstrates that the children suffering from pica in this series had a statistically significant higher birth weight as compared with the birth weights of a random sample of normal infants.

The present series of cases confirms the reported frequency of worm infestation in pica. The Cape Coloured children of this area are known to be commonly affected in this way and in a random sample of the hospital's out-patients 25 of 120 children $(21 \%)$ gave a history of worm infestation. The proportion of infestations in the pica group $(83 \%)$ is significantly higher. Nevertheless, no steps were taken to alter this situation during the trial of iron therapy. Worm ova were not looked for, but this in no way invalidates this observation as the same criteria (viz. history and eosinophilia) for determining the incidence were used in both the pica and the control groups. Any hypothetical bearing of the presence of intestinal worms on the aetiology of pica appears therefore, to have no substantial foundation in fact.

The somewhat indefinite evidence in the literature, namely Cooper's average I.Q.of $87 \%$, against the association of mental deficiency with pica was confirmed in the present series of cases.

The main factors appear to be nutrition and anaemia. The nutritional state of the children in this series was good in comparison with other children of similar age and background. The serum protein levels were significantly higher than those of a control group of 77 anaemic out-patients of comparable age and background. These latter showed a mean total serum protein of $5.67 \mathrm{~g} . \%$, serum albumin 3.39 g. $\%$ and serum globulin of $2 \cdot 28 \mathrm{~g} . \%$. The mean for the pica group was 
$7 \cdot 19$ g. $\%$ for total serum proteins, $3 \cdot 87$ g. $\%$ for serum albumin and $3.32 \mathrm{~g}$. \% for serum globulin.

While the total protein in the pica group is entirely adequate, it is apparent that the albumin levels are relatively low and the globulin fractions rather high (see Table 3). The reason for this is not apparent.

All the children showed iron deficiency anaemia to a greater or lesser extent. The haemoglobin levels were significantly lower than those in a control group of 70 unselected out-patients of comparable age and background. These latter, varying from 1 to 7 years in age, showed a mean haemoglobin of $10.52 \mathrm{~g}$. $\%$ with a standard deviation of 1.70 . The mean for the pica group was $7.89 \mathrm{~g}$. \%. The morphology of the red blood cells (as judged from the smear), the haemoglobin, P.C.V. and M.C.H.C., coupled with the response to therapy, indicated that the anaemia was of the iron deficiency type. The M.C.H.C., which is regarded as the most sensitive index of iron-deficiency anaemia (Latsky, 1943), was below normal in every patient, confirming the presence of an iron-deficient state.

The logical result of the above findings was to treat all these patients with iron. It must be emphasized that at the time of treatment of the pica no other medicaments (e.g. vermifuges or antibiotics) were employed. No psychological advice was given and the condition was treated purely as anaemia. Intramuscular iron was chosen in preference to oral iron in most cases, because previous experience had shown that the oral administration of medicines was not reliable in the type of population under consideration. Parenteral iron therapy was the only way of ensuring that the patient received the drug. The response to intramuscular therapy is quicker than to oral iron and, consequently, the number of hospital visits was reduced to a minimum. Previous writers have insisted that these cases were very resistant to medical treatment. Through the ages discouraging measures such as whipping or restraint of some sort have been the sheet anchor of therapy, and more recently the services of an energetic nanny (Sheldon, 1955) have been advocated. No such adjuvants to iron therapy were employed in this investigation.

'The effort to maintain a constant internal environment, or homeostasis, constitutes one of the most universal and powerful of all behaviour urges or drives' (Richter, 1943). Adrenalectomized rats, in a laboratory, consume unusual amounts of salt solution. Patients with Addison's disease crave salt and thereby provide an early and significant indication of the nature of their illness. Parathyroidectomized rats prefer calcium lactate solution to water and children with parathyroid deficiency show a craving for chalk and plaster. Diabetics drink excessive amounts of water and they and patients with thyrotoxicosis compensate for their increased metabolic needs by polyphagia. Davis (1928) showed that a child, given free choice of selection of food, would maintain itself in excellent nutrition in all respects without adult guidance. She reported on a rachitic child who voluntarily consumed codliver oil until about the time the blood calcium and phosphorus reached normal levels, and radiographs showed the rickets to be healed. Theiler, Green and Du Toit (1924), as quoted by Cooper (1957), described osteophagia in cattle as a herbivore's response to osteomalacia. The feeding of phosphorus-rich substances to the cattle resulted in the eradication of the pica.

If these children with pica do, in fact, feel an instinctive need for iron to restore their haemoglobin levels to normal a slight difficulty arises as to the child in this series who was given a blood transfusion yet continued to have pica. A similar query may be directed at the child who lost his pica without showing a rise in haemoglobin level. A possible explanation would be that the transfused blood although it corrected the anaemia contained an insufficient amount of iron $(35 \mathrm{mg} . / 100 \mathrm{ml}$.) to meet the needs of restoration and iron storage, and that in the other child it was really the storage-iron deficiency which was responsible for his condition. This is analogous to the presence of glossitis, dysphagia (sideropenic dysphagia) and koilonychia as a result of marked epithelial changes occurring in tissue-iron deficiency without anaemia (Waldenström and Kjellberg, 1939; Waldenström, 1946; Henderson, 1954; Bothwell and Glyn Thomas, 1958). This is a state of delicate metabolic equilibrium and blood transfusion restores the haemoglobin to normal but is insufficient to satisfy tissue needs. Thus treatment in pica must be adequate enough to correct anaemia, when present, and to refill the iron stores. Since it is extremely difficult to replenish body stores by the oral route (Finch, Haskins and Finch, 1950) it may be necessary in some instances, in addition to the reasons given above, to use parenteral iron in the treatment of this condition.

Since this paper was prepared eight further cases of pica have been seen. They all showed the typical clinical features already described, and all were cured by intramuscular iron-dextran compound (Imferon).

Finally, it must be admitted that the commonest mineral deficiency in children throughout the world is almost certainly iron, and a subconscious craving for it might well be expected. 


\section{Conclusions and Summary}

The literature on the subject of pica is briefly reviewed. An investigation of 12 children suffering from pica is described. The main abnormality found was an iron deficiency anaemia. Treatment of this with iron was invariably followed by the rapid disappearance of pica. The conclusion is drawn that iron deficiency is the major cause of pica and that iron therapy is curative.

I am indebted to Professor F. J. Ford, Head of the Department of Child Health, University of Cape Town, for his constant guidance, advice and criticism in the preparation of this paper, to Dr. J. D. L. Hansen and Dr. W. Emdin for their advice, and to Dr. J. F. Mostert, Medical Superintendent of the Red Cross War Memorial Children's Hospital, for permission to publish this work. Thanks are also due to the honorary physicians and colleagues who referred cases of pica to me, to $\mathrm{Mr}$. T. Turner for technical assistance in the serum protein estimations, and Mr. B. Todt for the photography.

\section{REFERENCES}

Boezo, M. H. (1638). (Quoted by Cooper, M.) De Pica. Sm., Lipsiae.

Bothwell, T. H. and Thomas, R. Glyn (1958). S. Afr. med. J., 32, 614

Butterworth, W. W. (1909). J. Amer, med. Ass., 53, 617.

Castro, J. de (1952). Geography of Hunger, p. 80. Gollancz, London.

Cooper, M. (1957). Pica. Charles C. Thomas, Springfield, Illinois. Cragin, F. W. (1835). (Quoted by Cooper, M.) Amer.J. med. Sci., $17,356$.

Davis, C. M. (1928). Amer. J. Dis. Child, 36, 651

Dickins, D. and Ford, R. N. (1942), Amer. Soc. Rev., 7, 59.

Dukes, C. (1884). Lancet, 2, 822.

Duprey, A. J. B. (1900). Ibid., 2, 1192.

Finch, S., Haskins, D. and Finch, C. A. (1950). J. clin. Invest., 29, 1078

Ford, F. J. (1958). Personal communication.

Gelfand, M. (1945). E. Afr. med. J., 22, 98.
Gould, A. N. (1876). (Quoted by Cooper, M.) Boston med. Surg. J., $94,417$.

Gros, H. (1903). (Quoted by Cooper, M.) La Caducée, 3, 248.

Hancock, J. (1831). (Quoted by Cooper, M.) Edinb. med. surg. J., 35,67 .

Henderson, I. D. (1954). Lancet, 1, 493

Hubrigkt, J. F. (1562), (Quoted by Cooper, M.) De Appetitu

Depravato Pica Dicto. Altdorff.
Kanner, L. (1948). Child Psychiatry, 2nd ed., p. 475. Charles C. Thomas, Springfield, Illinois

Kovatsch, W. (1879). (Quoted by Cooper, M.) Memorabilien, 24, 97.

Latsky, J. M. (1943). An experimental investigation into the blood in Cape Peninsula school children in relation to their nutritional state. Ph.D. Thesis. University of Cape Town.

McKhann, C. F. (1926). Amer. J. Dis. Child., 32, 386.

Major, W. (1935). (Quoted by Cooper, M.) Un. Méd. Can., 64, 1424.

Mathieu, J. (1927). (Quoted by Cooper. M.) Arch. Med. Enf., 30,591

Nims, H. (1842). (Quoted by Cooper, M.) Boston med. surg. J.,

Nouverre, M. G. (1833). (Quoted by Cooper, M.) J. Méd.

prat., 13, 65 .
Orr, J. B. and Gilks, J. L. (1931). Spec. Rep. Ser. med. Res. Coun. (Lond.) No. iss.

Peak, H. (1857). (Quoted by Cooper, M.) New Orleans med, surg. J., 13, 299.

Rake, B. (1884) Brit. med. J., 1, 994

Richter, C. P. (1943). Harvey Lect., 1942-43, Series 38, 63.

Ruddock, J. C. (1924). J. Amer. med. Ass., 82, 1682.

Schrey, W. H. (1719). (Quoted by Cooper, M.) De Appetitu Erroneo quem Vulgo Picam Vocunt. Dissertation. Literatis Immanuelis Titii, Leipsig.

Segond, A. (1833). (Quoted by Cooper, M.) Tr. Med. Paris, 13, 156.

Sheldon, W. (1955). Diseases of Infancy and Childhood, 7th ed., p. 613. J. \& A. Churchill. London.

Stetson, C. A. (1947). J. Maine med. Ass., 38, 10

Still, G. F. (1915). Common Disorders and Diseases of Childhood 3rd ed. p. $779 . \quad$ Henry Frowde, London.

Tanis, A. L. (1955). A.M.A. Amer. J. Dis. Child., 89, 325

Theiler, A., Green, H. H. and Du Toit, P. J. (1924). (Quoted by Cooper, M.) Phosphorus in the Live Stock Industry (re Osteophagia in S.A. cattle). Department of Agriculture, Union of South Africa.

Tosatti, C. (1907). (Quoted by Cooper, M.) Gazz. Osp. Clin. $28,154$.

Waldenström, J. and Kjellberg, S. R. (1939). Acta radiol. (Stockh.), 20,618 .

Acta med scand, Suppl 170, p. 252

Waller, H. (1874). The Last Journals of David Livingstone, in Centra Africa from 1865 to his Death, Vol. 2, p. 83. John Murray, London.

Williams, H., Kaplan, E., Couchman, C. and Sayers, R. (1955). (Quoted by Cooper, M.) Publ. Hlth Rep. (Wash.), 167, 3. 